\title{
Physico-Chemical Characterization and Mine Soil Genesis in Age Series Coal Mine Overburden Spoil in Chronosequence in a Dry Tropical Environment
}

\section{Jitesh Kumar Maharana and Amiya Kumar Patel*}

School of Life Sciences, Sambalpur University, At/Po-Jyoti Vihar, Burla-768019, Odisha, India

\begin{abstract}
A pre-requisite to any revegetation plan, as well as restoration of degraded land is the knowledge of physicochemical characterization, which is crucial for prediction of ecological succession for mine overburden spoil, including soil texture, hydrological regimes, $\mathrm{pH}$, organic carbon, nitrogen and extractable phosphorous. Effects of mining activities are markedly adverse, because many of the beneficial soil characteristics may require a long span of time to develop through pedogenic processes, in order to reach the native forest soil condition, which evaluates the degree of functional microbial processes for ecosystem recovery, and used as an index of the progress of soil genesis in mine overburden spoil. Mine spoil samples collected from six different age series overburdens showed progressive increase in clay $(\%)(r=0.982, p<0.001)$, water holding capacity and organic carbon, which indicates the development of soil structural stability, aggregation with the increase in age of overburden spoil. The $\mathrm{pH}$ of spoil samples was noted to be in acidic range (6.11-6.87). Approximately, 93.7\% variability in clay (\%) among different mine spoils can be explained due to the variation in organic carbon. The organic carbon, nitrogen and phosphorous content showed an improvement of $2 \mathrm{mg} \mathrm{C} / \mathrm{g}$ spoil, $161 \mu \mathrm{g} \mathrm{N} / \mathrm{g}$ spoil and $8 \mu \mathrm{g} \mathrm{P} / \mathrm{g}$ spoil, respectively, over a period of 10 years. Thus, the net annual accumulation rate for carbon, nitrogen and phosphorous on hectare basis amounted to $255 \mathrm{~kg} \mathrm{C} / \mathrm{ha} / \mathrm{yr}, 20 \mathrm{~kg} \mathrm{~N} / \mathrm{ha} /$ $\mathrm{yr}$ and $1 \mathrm{~kg} \mathrm{P} / \mathrm{ha} / \mathrm{yr}$, respectively. Further, it was estimated that the mine overburden spoil to attain the soil features of nearby native forest soil at study site through the process of reclamation, shall take approximately 28 years.
\end{abstract}

Keywords: Mine overburden spoil; Reclamation; Land degradation; Physico-chemical characterization

\section{Introduction}

Soil is a dynamic system, in which continuous interaction between soil minerals, organic matter and microorganisms influences the physico-chemical and biological properties of terrestrial ecosystem. Anthropogenic activities such as mining activities, specifically open cast mining, have resulted in drastic alternations in their geochemical cycles and often lead to land degradation, with adverse changes in soil textural and structural attributes [1-6]. Pit scarred landscape with huge dumps of mine spoils, in the form of overburden, usually presents the common scenario in the opencast coal mine area. Mine spoil, which refers to a mixture of coal seam, parent rock and subsoil $[7,8]$. Being deficient in plant nutrients due to lack of biologically rich top soil, mine spoil represents a disequilibriated geomorphic system $[9,10]$, and poses problem for the process of pedogenesis [11-13], revegetation $[7,14,15]$ and restoration $[4,16-18]$. There have been reports about slow recovery process of mine spoil due to the constraints of microbial growth [19$21]$, and natural vegetational succession $[7,17]$.

In view of the increasing mining activities, decreasing soil fertility and adverse effects on soil flora and fauna, it is of utmost concern to monitor the physico-chemical characteristics of coal mine overburden spoil in a chronosequence, which not only pave the way of greater understanding the direction of improving soil fertility and bioremediation, but also is pre-requisite for assessing the process of spoil reclamation, leading to the vegetational development/succession with respect to time. Since coal is one of the extensively mined and used for majority of purposes, coal mining based mine overburden and contaminants have become a major issue of environmental concern. Thus, an attempt was made in the present study to determine the spoil reclamation process, in terms of different soil textural (sand, slit and clay fraction), structural (bulk density) properties, hydrological regimes (water holding capacity, moisture content), and spoil chemical characteristics $\left(\mathrm{pH}\right.$, organic carbon, total nitrogen and $\mathrm{NaHCO}_{3}$ extractable phosphorous) in six different coal mine overburden spoils (fresh to $10 \mathrm{yr}$ ) in chronosequence, located in the open cast coal mine area of Odisha, India.

\section{Materials and Methods}

\section{Study site}

The present study was carried out in the Basundhara (west) open cast colliery, Ib valley coalfields area of Mahanadi Coalfields Limited (MCL), Sundargarh, Odisha (Geographical location: 22 $03^{\prime} 58^{\prime \prime}$ $20^{\circ} 04^{\prime} 11^{\prime \prime}$ north latitude and $83^{\circ} 42^{\prime} 46^{\prime \prime}-83^{\circ} 44^{\prime} 45^{\prime \prime}$ east longitude). Topologically, the area is hilly sloppy to plateau. The thickness of the native top soils in the study site varies from $0.15 \mathrm{~m}$ to $0.30 \mathrm{~m}$ (average: $0.22 \mathrm{~m}$ ). Because of the mining activities and limited original soil materials, there is insufficient soil to allow successful revegetation. The area experiences a semi-arid climate with annual rain fall of $1514 \mathrm{~mm}$ $\mathrm{yr}^{-1}$, annual average temperature of $26^{\circ} \mathrm{C}$ and relative humidity of $15 \%$. Open cast mining activities lead to the formation of coal mine spoil overburdens, and were grouped according to the time elapsed (Fresh mine spoil: $\mathrm{OB}_{0}, 2 \mathrm{yr}: \mathrm{OB}_{2}, 4 \mathrm{yr}: \mathrm{OB}_{4}, 6 \mathrm{yr}: \mathrm{OB}_{6}, 8 \mathrm{yr}: \mathrm{OB}_{8}$ and $10 \mathrm{yr}: \mathrm{OB}_{10}$ respectively), since abandonment. The moisture index (calculated from annual rainfall and potential evapo-transcription data) of the district is -20.7. Thus, tropical dry deciduous forest is considered to be the natural vegetation of the study site, and broadly the climate is dry, hot and arid,

\footnotetext{
*Corresponding author: Amiya Kumar Patel, School of Life Sciences, Sambalpur University, At/Po-Jyoti Vihar, Burla-768019, Odisha, India, Tel: +91-9338686900 Fax: +91-663-2430158; E-mail: amiya_gene@yahoo.com
}

Received January 21, 2012; Accepted February 15, 2013; Published February 25, 2013

Citation: Jitesh Kumar M, Amiya Kumar P (2013) Physico-Chemical Characterization and Mine Soil Genesis in Age Series Coal Mine Overburden Spoil in Chronosequence in a Dry Tropical Environment. J Phylogen Evolution Biol 1: 101. doi:10.4172/2329-9002.1000101

Copyright: (C) 2013 Jitesh Kumar M, et al. This is an open-access article distributed under the terms of the Creative Commons Attribution License, which permits unrestricted use, distribution, and reproduction in any medium, provided the original author and source are credited. 
and shows the characteristics of seasonality with three distinct seasons, i.e. summer (March to mid-June), rainy (mid-June to mid of October) and winter (October to February).

\section{Spoil sampling}

Each age series mine overburden was divided into 5 blocks and from each block, five mine spoil samples were collected randomly from $0-15 \mathrm{~cm}$ soil depth, by digging pits $(15 \times 15 \times 15) \mathrm{cm}^{3}$ size. Samples collected from each block were referred as 'sub-samples', and were thoroughly mixed to form one 'composite sample', obtained from each overburden site. Similar strategy has been followed for sampling from different age series of coal mine overburden, along with nearby native forest soil (NF) in three different seasons, i.e. summer (April), rainy (July) and winter (January). The composite samples were homogenized, sieved $(0.2 \mathrm{~mm})$ and stored at $4^{\circ} \mathrm{C}$, until analyzed.

\section{Spoil texture}

Spoil texture analysis included the estimation of clay $(<0.002 \mathrm{~mm})$, silt $(0.06 \mathrm{~mm}-0.002 \mathrm{~mm})$ and sand $(2 \mathrm{~mm}-0.06 \mathrm{~mm})$ percentage. Spoil sample $(50 \mathrm{~g})$ was taken in a $500 \mathrm{ml}$ heat resistant bottle, calibrated up to $250 \mathrm{ml}$. To this, $125 \mathrm{ml}$ of water was added and the mixture was swirled to wet the spoil thoroughly. $20 \mathrm{ml}$ of $30 \%$ hydrogen peroxide was added to it and the bottle was gently rotated. Few drops of amyl alcohol were added to the mixture and kept in a boiling water bath, till the reaction was complete. Then, $2 \mathrm{~g}$ of sodium hexametaphosphate was added, followed by water, to make it up to $250 \mathrm{ml}$, and was shaken for $28 \mathrm{hr}$ in a mechanical shaker. Then, the contents were transferred to a 1 $\mathrm{L}$ sedimentation cylinder and the volume was made up to $1 \mathrm{~L}$. A blank cylinder was maintained by dissolving $2 \mathrm{~g}$ of sodium hexametaphosphate in water and made up to the mark with water. Both experimental and blank samples were placed in a water bath to maintain a constant temperature $\left(25 \pm 2^{\circ} \mathrm{C}\right)$. After $30 \mathrm{~min}$, the sample cylinder was mixed vigorously with a plunger. The Bouyoucos hydrometer readings were taken exactly at $40 \mathrm{sec}$ and $5 \mathrm{hr}$ for the samples, and at $5 \mathrm{hr}$ for the blank. Temperature of the water bath was recorded. The percentage of sand, silt and clay were determined as per the following calculation.

$40 \mathrm{sec}($ corr $)=2(40 \mathrm{sec}$ reading $-40 \mathrm{sec}$ blank $+\mathrm{T})$

$5 \mathrm{hr}($ corr $)=2(5 \mathrm{hr}$ reading $-5 \mathrm{hr}$ blank $+\mathrm{T})$

Where, $\mathrm{T}=$ Temperature corrections:

For every degree centigrade above $20^{\circ} \mathrm{C}(\mathrm{d}), \mathrm{T}=0.3 \times \mathrm{d}$

For every degree centigrade below $20^{\circ} \mathrm{C}(\mathrm{d}), \mathrm{T}=-0.3 \times \mathrm{d}$

$\%$ sand $=100-40 \sec$ (corr)

$\%$ silt $=40 \mathrm{sec}$ (corr) $-5 \mathrm{hr}$ (corr)

$\%$ clay $=5 \mathrm{hr}$ (corr)

\section{Bulk density}

Bulk density of the mine spoil was calculated, following the method prescribed in TSBF Handbook [22]. A pit of $10 \mathrm{~cm}$ length $\times 10 \mathrm{~cm}$ breadth $\times 20 \mathrm{~cm}$ depth was dug, and the soil was excavated. The collected soil was dried in an oven at $105^{\circ} \mathrm{C}$ for $24 \mathrm{hr}$. Dry weight of the soil was determined. The pit was filled with known volume of dry sand. The bulk density $\left(\mathrm{g} / \mathrm{cm}^{3}\right)$ was calculated as: [weight of excavated soil (in $\left.\mathrm{g}\right) /$ volume of sand $\left.\left(\mathrm{cm}^{3}\right)\right]$.

\section{Water Holding Capacity (WHC)}

WHC was determined, following the protocol proposed by Mishra [23]. Soil samples from the different age series mine spoil samples were collected, air dried and crushed to pass through $0.5 \mathrm{~mm}$ mesh sieve. A brass box with perforated bottom was taken, and a Whatman circular filter paper (No. 42) was placed on the perforated bottom. A split brass ring was used to press the filter paper to its position. The box along with the filter paper was weighed and recorded as $\mathrm{W}_{1}$. The brass box was filled with soil, with constant tapping, to ensure uniform packing. The soil packed box was placed on a petridish and water was added to maintain the depth of $1 \mathrm{~cm}$. From time to time, water was added to maintain the depth. The box was left in the position for $12 \mathrm{hr}$. After that, the box was removed, subjected to surface drying with blotting paper, and the weight of the box was recorded $\left(\mathrm{W}_{2}\right)$. The box was then placed in the oven at $105^{\circ} \mathrm{C}$ for $24 \mathrm{hr}$, and the dry weight was recorded as $\mathrm{W}_{3}$. Water absorbed by the filter paper was determined by saturating five filter papers with water, and weighing after rolling with a glass rod. The average amount of water absorbed by one filter paper was determined as $\mathrm{W}_{4}$. The $\mathrm{WHC}(\%)$ of the soil was calculated as: $\left[\left(\mathrm{W}_{2}-\mathrm{W}_{3}-\mathrm{W}_{4}\right) /\left(\mathrm{W}_{3}\right.\right.$ $\left.\left.\mathrm{W}_{1}\right)\right] \times 100$.

\section{Moisture content}

About $10 \mathrm{~g}$ of coal mine overburden soil samples were taken $\left(\mathrm{W}_{1}\right)$. The samples were oven dried at $105^{\circ} \mathrm{C}$ for $24 \mathrm{hr}$ or more, till a constant dry weight was obtained $\left(\mathrm{W}_{2}\right)$. The soil moisture (\%) was calculated as: $\left[\left(\mathrm{W}_{1}-\mathrm{W}_{2}\right) / 10\right] \times 100$.

\section{Soil pH}

Air dried soil of $20 \mathrm{~g}$ was taken in a beaker, and to this $50 \mathrm{ml}$ of water was added. The mixture was stirred for $10 \mathrm{~min}$, and was allowed to stand for $30 \mathrm{~min}$. The $\mathrm{pH}$ was measured by use of electronic digital pH meter (Make: Systronics, Model: MK VI).

\section{Organic carbon}

Soil organic carbon was estimated, following titration method of Walkley and Black by Mishra [23]. To $5 \mathrm{~g}$ of oven dried mine spoil, $10 \mathrm{ml}$ of $1 \mathrm{~N} \mathrm{~K}_{2} \mathrm{Cr}_{2} \mathrm{O}_{7}$ and $20 \mathrm{ml}$ of conc. $\mathrm{H}_{2} \mathrm{SO}_{4}$ were added in a 500 $\mathrm{ml}$ Erlenmeyer flask, thoroughly shaken for $5 \mathrm{~min}$, and was allowed to stand for $30 \mathrm{~min}$. The suspension was diluted with $200 \mathrm{ml}$ of distilled water, followed by $1 \mathrm{ml}$ of $85 \% \mathrm{H}_{3} \mathrm{PO}_{4}$, and $1 \mathrm{ml}$ of diphenylamine indicator. The mixture was titrated against $1 \mathrm{~N}\left(\mathrm{NH}_{4}\right)_{2} \mathrm{Fe}\left(\mathrm{SO}_{4}\right)_{2} .6 \mathrm{H}_{2} \mathrm{O}$, until the colour of the mixture flashed to green. Then, $0.5 \mathrm{ml}$ of $1 \mathrm{~N}$ $\mathrm{K}_{2} \mathrm{Cr}_{2} \mathrm{O}_{7}$ was added, and the titration was completed by adding $1 \mathrm{~N}$ $\left(\mathrm{NH}_{4}\right)_{2} \mathrm{Fe}\left(\mathrm{SO}_{4}\right)_{2} \cdot 6 \mathrm{H}_{2} \mathrm{O}$, till the last traces of blue color disappeared. Organic carbon (\%) was calculated as: $\left[\left(\mathrm{V}_{1}-\mathrm{V}_{2}\right) / \mathrm{W}\right] \times 0.003 \times 100$; where $\mathrm{V}_{1}=$ volume of $1 \mathrm{~N} \mathrm{~K}_{2} \mathrm{Cr}_{2} \mathrm{O}_{7} ; \mathrm{V}_{2}=$ volume of $1 \mathrm{~N}\left(\mathrm{NH}_{4}\right)_{2} \mathrm{Fe}\left(\mathrm{SO}_{4}\right)_{2} \cdot 6 \mathrm{H}_{2} \mathrm{O}$; $\mathrm{W}=\mathrm{wt}$ of spoil sample.

\section{Total nitrogen}

Total soil nitrogen was determined by Kjeldahl method [24]. Spoil sample of $10 \mathrm{~g}$ was transferred to a $300 \mathrm{ml} \mathrm{Kjeldahl} \mathrm{flask} \mathrm{and} \mathrm{was}$ moistened with $25 \mathrm{ml}$ of distilled water; allowed to stand for $30 \mathrm{~min}$. To it, $20 \mathrm{~g}$ of sodium sulfate and the catalyst mixture ( $20 \mathrm{~g}$ copper sulfate, $3 \mathrm{~g}$ of mercuric oxide, $1 \mathrm{~g}$ selenium powder) was added. To one part of this mixture, 20 parts of anhydrous sodium sulfate was added, and a pinch of granulated zinc was added to the suspension, followed by $35 \mathrm{ml}$ of conc. $\mathrm{H}_{2} \mathrm{SO}_{4}$. The resulting mixture was subjected to low heat treatment for $30 \mathrm{~min}$ for digestion, till the digest become yellow and colorless. The digest was then cooled and $100 \mathrm{ml}$ of water was added, and allowed to stand for $5 \mathrm{~min}$. The supernatant was then transferred into a flask. $25 \mathrm{ml}$ of $4 \%$ boric acid was pipetted into a $500 \mathrm{ml}$ conical flask, and 5 drops of mixed indicator ( $0.5 \mathrm{~g}$ bromo-cresol green and 0.1 g methyl red dissolved in $100 \mathrm{ml}$ of $95 \%$ ethyl alcohol) was added. The glass tube attached to the lower end of the condenser was dipped into 
the boric acid solution. The condenser was connected to the flask and $100 \mathrm{ml}$ of $40 \% \mathrm{NaOH}$ was added slowly through the separating funnel. By heating the mixture, $150 \mathrm{ml}$ of distillate was collected in the conical flask and was titrated against $\mathrm{N} / 14 \mathrm{H}_{2} \mathrm{SO}_{4}$, till the faint pink coloration was reached. A blank was run instead of spoil. Total soil nitrogen (\%) was calculated as: $[(\mathrm{T}-\mathrm{B}) \times \mathrm{N} \times 14.007 \times 100] / \mathrm{W}$; where $\mathrm{T}$ and $\mathrm{B}$ are the volume of titrant used against sample and blank; $\mathrm{N}=$ normality of titrant and $\mathrm{W}=$ weight of sample.

\section{$\mathrm{NaHCO}_{3}$ extractable phosphorous}

The phosphorous content in mine spoil was estimated by using chlorostannous reduced molybdophosphoric blue colour method in $\mathrm{HCl}$ [25]. Molybdophosphoric acid, which is thought to be formed by the coordination of molybdate ions, with phosphorous, as the central coordinating atom. The oxygen of the molybdate radicals is being substituted by that of phosphate ions, and the formation of molybdophosphoric acid. Sieved and air dried spoil sample of $5 \mathrm{~g}$ was transferred to a $250 \mathrm{ml}$ conical flask, and to it $50 \mathrm{ml}$ of $0.03 \mathrm{~N} \mathrm{NH}_{4} \mathrm{~F}$ in $0.025 \mathrm{~N} \mathrm{HCl}$ was added and was shaken for $5 \mathrm{~min}$, and filtered immediately. To $2.5 \mathrm{ml}$ of the filtrate, $7.5 \mathrm{ml}$ of ammonium molybdate was mixed thoroughly, followed by addition of freshly prepared $0.5 \mathrm{ml}$ of $\mathrm{SnCl}$ solution, and allowed to stand for 4-20 min. The absorbance was measured at $660 \mathrm{~nm}$, and extractable soil phosphorous content was expressed in $\mu \mathrm{g} / \mathrm{g}$ spoil.

\section{Statistical Analysis}

All the composite samples collected from six different age series mine overburden and native forest were analyzed, with respect to different parameters in triplicates. Microsoft Excel 97 was used in the statistical processing of the data. Principal components analysis (PCA) was performed using Statistrix PC DOS Version-2.0 (NH Analytical software).

\section{Results}

Textural characteristics, bulk density, different hydrological regimes and $\mathrm{pH}$ of mine spoil samples $\left(\mathrm{OB}_{0} \rightarrow \mathrm{OB}_{10}\right)$ have been presented in table 1 . The analysis indicated that the slit and clay (\%) did exhibit an increasing trend from $\mathrm{OB}_{0}$ to $\mathrm{OB}_{10}$. However, the sand (\%) showed a reverse trend. Analysis of variance (two way ANOVA) indicated that the textural variation in different age series mine overburden spoils was estimated to be significant $(p<0.001)$. Further, the clay fraction of different spoil samples was marked to be statistically correlated with the age of spoils $(r=0.982,(p<0.001)$, which indicated that $96.46 \%$ of the variability in clay (\%) was accounted by the age of mine overburden spoil.

Bulk density was found to be maximum in $\mathrm{OB}_{0}\left(1.752 \mathrm{~g} / \mathrm{cm}^{3}\right)$, but it showed a declining trend with the increase in age of mine overburden (Table 1). In $\mathrm{OB}_{10}$, bulk density was estimated to be minimum. However, water holding capacity showed the reverse trend, i.e. minimum in $\mathrm{OB}_{0}$ $(27.5 \pm 1.121)$, and progressively increased with time (maximum in $\left.\mathrm{OB}_{10}: 43.8 \%\right)$. The moisture content was found to be minimum in $\mathrm{OB}_{0}$ $(6.831 \pm 0.103)$, and showed an increasing trend with the increase in age of mine spoil, i.e. maximum in $\mathrm{OB}_{10}(7.955 \pm 0.087)$. Spoil $\mathrm{pH}$ of all the sites was in the acidic range (6.11-6.87). The $\mathrm{pH}$ of $\mathrm{OB}_{0}$ was minimum (6.11) and maximum in $\mathrm{OB}_{10}$ (6.71). Study on soil $\mathrm{pH}$ indicated that with the increasing age of the overburden, soil $\mathrm{pH}$ progressed towards the neutral range (Table 1).

The clay (\%) exhibited by the nearby native forest soil (12.1\%) was more than two times greater than $\mathrm{OB}_{0}$. The bulk density, water holding capacity and moisture content in NF was found to be $1.252 \mathrm{~g} / \mathrm{cm}^{3}$, $46.348 \%$ and $11.219 \%$, respectively. The soil $\mathrm{pH}$ of NF was found to be closer to neutral range, as compared to $\mathrm{OB}_{0}$ (Table 1).

It is evident from the data that the organic carbon, total nitrogen and extractable phosphorous content in $\mathrm{OB}_{0}$ were beyond the detectable limit. In addition, extractable phosphorous, even in $\mathrm{OB}_{2}$, was also not detected (Table 2). The organic carbon, total nitrogen and extractable phosphorous in spoil samples collected from different age series mine overburdens showed a range from $0.151-2.004 \mathrm{mg} \mathrm{C} / \mathrm{g}$ spoil, 8.514$169.830 \mu \mathrm{g} \mathrm{N} / \mathrm{g}$ spoil and 4.254-12.581 $\mu \mathrm{g} \mathrm{P} / \mathrm{g}$ spoil, respectively, with minimum in $\mathrm{OB}_{2}$ and maximum in $\mathrm{OB}_{10}$.

The analysis suggested that there was gradual increase in organic carbon, total nitrogen and extractable phosphorous, from $\mathrm{OB}_{0}$ to $\mathrm{OB}_{10}$ Further, the analysis of variance showed that there was significant variation in organic carbon $(\mathrm{r}=0.992 ; p<0.001)$, total nitrogen $(\mathrm{r}=0.979$; $p<0.001)$ and extractable phosphorous $(\mathrm{r}=0.980 ; p<0.001)$, in different mine spoil samples in chronosequence, with respect to the age of mine overburden. However, the organic carbon, total nitrogen and extractable phosphorous in NF was found to be $3.625 \mathrm{mg} \mathrm{C} / \mathrm{g}$ soil, 2510 $\mu \mathrm{g} \mathrm{N} / \mathrm{g}$ soil and $275 \mu \mathrm{g} \mathrm{P} / \mathrm{g}$ soil, respectively (Table 2).

\section{Discussion}

The soil samples collected from six different age series mine overburdens showed variation in soil texture, which may be due to the variation in clay (\%). Clay (\%) showed progressive increase with the increase in age of overburden. Gradual establishment of the vegetation cover on the overburden can be one of the reasons for the increase in the clay formation $[7,26,27]$. Root of the vegetational component, specifically root exudates in the form of organic acids, promotes disintegration of coarse particles to finer clay particles [26,27]. Besides, the absence of vegetational cover makes clay more prone to loss $[28,29]$. On the other hand, vegetational cover development on degraded barren land was reported to check the loss of clay particles, and promotes

\begin{tabular}{|c|c|c|c|c|c|c|c|}
\hline \multirow[b]{2}{*}{ Parameters } & \multicolumn{6}{|c|}{ Coal mine spoil from different overburdens } & \multirow[b]{2}{*}{ NF } \\
\hline & $\mathrm{OB}_{0}$ & $\mathrm{OB}_{2}$ & $\mathrm{OB}_{4}$ & $\mathrm{OB}_{6}$ & $\mathrm{OB}_{8}$ & $\mathrm{OB}_{10}$ & \\
\hline Sand $(\%)$ & $86.8 \pm 2.1$ & $84.6 \pm 1.5$ & $81.4 \pm 1.6$ & $79.5 \pm 1.1$ & $77.8 \pm 1.2$ & $75.9 \pm 1.8$ & $74.1 \pm 1.2$ \\
\hline Silt (\%) & $7.8 \pm 0.6$ & $8.5 \pm 0.6$ & $9.9 \pm 0.3$ & $10.6 \pm 0.8$ & $11.5 \pm 0.5$ & $12.8 \pm 1.2$ & $14.2 \pm 0.6$ \\
\hline Clay $(\%)$ & $5.4 \pm 1.2$ & $6.9 \pm 0.7$ & $8.7 \pm 0.9$ & $9.9 \pm 0.6$ & $10.7 \pm 0.8$ & $11.3 \pm 1.3$ & $12.1 \pm 0.5$ \\
\hline $\begin{array}{l}\text { Bulk Density } \\
\left(\mathrm{g} / \mathrm{cm}^{3}\right)\end{array}$ & $1.752 \pm 0.049$ & $1.605 \pm 0.021$ & $1.364 \pm 0.019$ & $1.331 \pm 0.028$ & $1.294 \pm 0.026$ & $1.275 \pm 0.014$ & $1.252 \pm 0.019$ \\
\hline WHC (\%) & $27.5 \pm 1.121$ & $31.3 \pm 1.005$ & $36.1 \pm 0.984$ & $38.3 \pm 0.833$ & $41.2 \pm 0.743$ & $43.8 \pm 1.413$ & $46.348 \pm 0.833$ \\
\hline Moisture (\%) & $6.831 \pm 0.103$ & $7.138 \pm 0.141$ & $7.422 \pm 0.097$ & $7.541 \pm 0.143$ & $7.783 \pm 0.121$ & $7.955 \pm 0.087$ & $11.219 \pm 0.132$ \\
\hline Soil pH & $6.11 \pm 0.03$ & $6.24 \pm 0.04$ & $6.38 \pm 0.02$ & $6.45 \pm 0.05$ & $6.62 \pm 0.07$ & $6.71 \pm 0.06$ & $6.87 \pm 0.07$ \\
\hline
\end{tabular}

(Values are mean \pm SD of three seasons, i.e. summer, rainy and winter).

Table 1: Textural composition, bulk density, water holding capacity, moisture content and $\mathrm{pH}$ of mine spoil samples collected from age series overburdens, as well as native forest soil. 
Citation: Jitesh Kumar M, Amiya Kumar P (2013) Physico-Chemical Characterization and Mine Soil Genesis in Age Series Coal Mine Overburden Spoil in Chronosequence in a Dry Tropical Environment. J Phylogen Evolution Biol 1: 101. doi:10.4172/2329-9002.1000101

Page 4 of 7

\begin{tabular}{|c|c|c|c|c|c|c|c|c|}
\hline \multirow[b]{2}{*}{ Parameters } & \multirow[b]{2}{*}{ Season } & \multicolumn{6}{|c|}{ Coal mine spoil from different overburdens } & \multirow{2}{*}{$\begin{array}{l}\text { Native Forest } \\
\text { soil (NF) }\end{array}$} \\
\hline & & $\mathrm{OB}_{0}$ & $\mathrm{OB}_{2}$ & $\mathrm{OB}_{4}$ & $\mathrm{OB}_{6}$ & $\mathrm{OB}_{8}$ & $\mathrm{OB}_{10}$ & \\
\hline \multirow{4}{*}{$\begin{array}{l}\text { Organic C } \\
\text { (mg C/g spoil) }\end{array}$} & Summer & $\mathrm{ND}^{*}$ & $0.130 \pm 0.011$ & $0.721 \pm 0.018$ & $0.896 \pm 0.029$ & $1.104 \pm 0.026$ & $1.692 \pm 0.031$ & $3.282 \pm 0.024$ \\
\hline & Rainy & $\mathrm{ND}^{*}$ & $0.175 \pm 0.014$ & $0.824 \pm 0.014$ & $1.177 \pm 0.021$ & $1.881 \pm 0.033$ & $2.212 \pm 0.019$ & $3.867 \pm 0.021$ \\
\hline & Winter & $\mathrm{ND}^{*}$ & $0.148 \pm 0.023$ & $0.792 \pm 0.022$ & $1.098 \pm 0.031$ & $1.614 \pm 0.025$ & $2.108 \pm 0.024$ & $3.726 \pm 0.013$ \\
\hline & Mean & $\mathrm{ND}^{*}$ & $0.151 \pm 0.024$ & $0.779 \pm 0.048$ & $1.057 \pm 0.127$ & $1.533 \pm 0.242$ & $2.004 \pm 0.249$ & $3.625 \pm 0.25$ \\
\hline \multirow{4}{*}{$\begin{array}{l}\text { Total N } \\
\text { ( } \mu \mathrm{g} \mathrm{N/g} \mathrm{spoil)}\end{array}$} & Summer & $\mathrm{ND}^{*}$ & $8.121 \pm 0.112$ & $43.119 \pm 0.326$ & $68.151 \pm 1.618$ & $108.823 \pm 1.612$ & $159.104 \pm 2.61$ & $2354.09 \pm 17.3$ \\
\hline & Rainy & $\mathrm{ND}^{*}$ & $8.973 \pm 0.331$ & $48.268 \pm 0.224$ & $76.904 \pm 1.712$ & $117.197 \pm 1.236$ & $179.074 \pm 2.1$ & $2615.21 \pm 19.4$ \\
\hline & Winter & $\mathrm{ND}^{*}$ & $8.448 \pm 0.214$ & $46.112 \pm 0.102$ & $73.633 \pm 1.512$ & $114.645 \pm 1.221$ & $171.312 \pm 2.35$ & $2560.69 \pm 21.51$ \\
\hline & Mean & $\mathrm{ND}^{*}$ & $8.514 \pm 0.425$ & $45.833 \pm 2.248$ & $72.896 \pm 4.078$ & $113.555 \pm 3.901$ & $169.830 \pm 8.95$ & $2510 \pm 28.43$ \\
\hline \multirow{4}{*}{$\begin{array}{l}\text { Extractable P } \\
\text { ( } \mu \mathrm{g} \mathrm{P/g} \mathrm{spoil)}\end{array}$} & Summer & $\mathrm{ND}^{*}$ & $\mathrm{ND}^{*}$ & $2.728 \pm 0.311$ & $6.031 \pm 0.212$ & $10.170 \pm 0.029$ & $10.824 \pm 0.118$ & $263.34 \pm 3.22$ \\
\hline & Rainy & $\mathrm{ND}^{*}$ & $\mathrm{ND}^{*}$ & $5.472 \pm 0.451$ & $9.711 \pm 0.401$ & $11.928 \pm 0.113$ & $14.022 \pm 0.109$ & $284.29 \pm 4.65$ \\
\hline & Winter & $\mathrm{ND}^{*}$ & ND* & $4.562 \pm 0.239$ & $8.447 \pm 0.141$ & $11.085 \pm 0.042$ & $12.897 \pm 0.216$ & $277.36 \pm 3.4$ \\
\hline & Mean & $\mathrm{ND}^{*}$ & ND* & $4.254 \pm 1.246$ & $8.063 \pm 1.636$ & $11.061 \pm 0.764$ & $12.581 \pm 1.411$ & $275 \pm 9.97$ \\
\hline
\end{tabular}

* Not detectable. (Values are mean \pm SD of three seasons, i.e. summer, rainy and winter).

Table 2: Soil organic $\mathrm{C}$, total $\mathrm{N}$ and Extractable $\mathrm{P}$ content in mine spoil samples collected from different age series overburdens as well as native forest soil.

its conservation [7,30]. Clay being an important primary particle, contributes to the soil structural stability [31-33]. Progressive increase in clay particle in mine spoil indicated progressive development of soil structural stability, aggregation, and developed resistance to erosion, with the increase in age of mine overburden [7,17,29,34].

A positive relationship was observed between clay (\%) and organic carbon (mg C/g soil) between different overburden sites ( $\mathrm{r}=0.967$, $p<0.001)$. Increase in organic carbon was found to be correlated with the increase in clay fraction in ecologically disturbed lands $[35,36]$. According to Marshman and Marshall [37], clay acts as an absorption sink for organic material. Increase in organic fraction, with the increase in clay, can also be due to the fact that organic complexes being absorbed onto the clay surface, are being physically protected against decomposition $[38,39]$, which lead to an accumulation of soil organic carbon level, with respect to age of mine overburden. Organic carbon, in association with the primary soil particles, is reported to promote macro aggregation $[16,40]$. Beneficial influence of organic matter on soil aggregate formation, soil structural stability and nutrient retention capacity, has been extensively reviewed $[41,42]$.

Further, the study revealed a declining trend of bulk density with age of mine overburden, which is analyzed to be negatively correlated $(\mathrm{r}=0.917, p<0.001)$. Importance of bulk density lies with the fact that it regulates space, air and water availability to soil organisms [43]. A decline in bulk density, with age of mine spoil, can be interpreted as a reduction in soil compactness, because of the development of soil micropore space $[44,45]$. According to Ohta and Effendi [45], it is the clay fraction, which has an ultimate bearing on the soil bulk density. An increased level of clay fraction contributes to the development of soil micropore space that reduces the soil bulk density. In the light of this concept, the gradual accumulation of clay fraction and organic matter input in $\mathrm{OB}_{10}$ because of the vegetation, led to the development of soil micropore space, that ultimately reduced the soil bulk density. A negative relation between bulk density and organic $\mathrm{C}(\mathrm{r}=-0.903, p<0.01)$ of spoil samples collected from different age series of mine overburdens substantiated the concept $[7,18,46,47]$. Organic $C$ in association with primary soil particle was reported to promote macro aggregation $[40,45]$ and hence, soil bulk density declines.

WHC of the soil samples collected from different age series mine overburden exhibited an increasing trend, and was positively correlated with the age of overburden $(\mathrm{r}=0.991, p<0.001)$. Soil moisture showed progressive improvement with age of mine spoil, which is supported by the findings of Dutta and Agarwal [27]. This can be due to the positive influence of the canopy cover on the $\mathrm{OB}_{10}$ mine spoil, which prevented the loss of soil water through evaporation, by not allowing direct exposure of soil surface to the incoming radiation $[5,48,49]$. Several researchers also reported lower clay fraction, high soil bulk density, low water holding capacity and poor physical conditions of mine spoil $[17,18,26,27,50,51]$.

The mine spoils collected from $\mathrm{OB}_{0}$ showed the maximum acidic value and exhibited gradual improvement with the age of spoils. Improving soil chemical condition by the reduction of soil acidity has been well explained [6,52]. Acidification in the mine spoil due to different mineral deposits in the mine spoil $[6,17,27,52,53]$. Improvement of $\mathrm{pH}$ value due to both passive and active reclamation, either by natural succession or by the plantation strategy on coal mine overburden spoil $[7,27]$. Promotion of organic matter decomposition on degraded soil also has been reported to lower soil acidity $[47,53,54]$.

Organic $\mathrm{C}$ in spoil samples collected from different age series mine overburdens showed a considerable improvement, suggesting the restoration of coal mine spoils $[7,42,55,56]$. Establishment of vegetation and increase input of litter from the vegetation compartment, during the course of passive or active restoration, is supplemented by the improvement in soil organic carbon [57]. Along with the increase in organic $\mathrm{C}$, total $\mathrm{N}$ and extractable $\mathrm{P}$ also did exhibit gradual improvement, and showed positive relationship with age of overburden. Thus, the study clearly revealed that with the passage of time, spoils on overburden showed the sign of restoration, accumulating carbon, nitrogen and phosphorous to support the vegetational and soil biodiversity. Comparative assessment of soil organic $\mathrm{C}, \mathrm{N}$ and $\mathrm{P}$ levels between $\mathrm{OB}_{0}$ and $\mathrm{OB}_{10}$ samples indicated an improvement of $2 \mathrm{mg} \mathrm{C} / \mathrm{g}$ spoil, $161 \mu \mathrm{g} \mathrm{N} / \mathrm{g}$ spoil and $8 \mu \mathrm{g} \mathrm{P} / \mathrm{g}$ spoil, respectively over a period of 10 years. Thus, the net annual accumulation rate for $\mathrm{C}, \mathrm{N}$ and $\mathrm{P}$ amounted to 200, 16.1 and $0.8 \mu \mathrm{g} / \mathrm{g}$ spoil, respectively. On hectare basis, these figures correspond to $255 \mathrm{~kg} \mathrm{C} / \mathrm{ha} / \mathrm{yr}, 20 \mathrm{~kg} \mathrm{~N} / \mathrm{ha} / \mathrm{yr}$ and $1 \mathrm{~kg} \mathrm{P} /$ ha/yr, respectively.

Several workers have been reported that the nutrient accumulation in the disturbed land is a time dependent process. While working on the impact of natural succession/restoration of degraded barren tropical soil, Sahani and Behera [47,54] reported a net annual carbon accumulation of $800-1000 \mathrm{~kg} \mathrm{C} / \mathrm{ha}$. Hence, the present carbon accumulation data in the mine spoil is marked to be lower than that of Sahani and Behera [54] and Dutta and Agarwal [27]. This may be due to the hostile ambience of mine spoil, where natural successional process leading to the establishment of vegetation cover may be a much slower 
process. Visser et al. [21],Vimmerstedt et al. [31] and Jencks et al. [58], working on mine spoil reclamation in temperate climate reported a net nitrogen accumulation of 9.5 to $17 \mathrm{~kg} \mathrm{~N} / \mathrm{ha}$, and the figure of nitrogen accumulation estimated for the present study is $20 \mathrm{~kg} \mathrm{~N} / \mathrm{ha}$. Successional establishment of many leguminous herbaceous species on mine spoil in tropical environment can explain such higher $\mathrm{N}$ accumulation rate. Dancer et al. [59] have suggested that $700 \mathrm{~kg} \mathrm{ha}^{-1}$ of $\mathrm{N}$ accumulation in soil is critical for the establishment of a substantial self-sustaining ecosystem in disturbed lands. Roberts et al. [35] and Dancer et al. [59] have identified accumulation of nutrients as an important feature of ecosystem development in naturally colonized spoils. The increase in soil $\mathrm{N}$ can be attributed to the input from the growing plant species, i.e. Cassia siamea and Acacia auriculaeformis in mine spoil, in course of time, which are reported to have a good nitrogen fixing potential $[60,61]$. Besides, A. auriculaeformis is considered to be a tolerant species, which flourishes well in marginal acid soil with low nutrient [61]. Even after 10 years of restoration, the nitrogen level in mine spoil still observes to remain below the critical limit, which urges the management strategy for planned restoration of mine overburden spoil. With respect to soil phosphorous, the development of mycorrhiza and other phosphorous immobilizing microbial colonization in the coal mine overburden spoil, may be the reason for such accumulation.

Considering the tropical dry deciduous forest as natural vegetation of the study site, attempt was made to compare the spoil features of different mine spoils $\left(\mathrm{OB}_{0} \rightarrow \mathrm{OB}_{10}\right)$ in chronosequence, with that of NF soil using principle component analysis [62], in which the $\mathrm{Z}_{1}$ and $\mathrm{Z}_{2}$ components accounts for $99 \%$ cumulative variance (Figure 1).

Besides, the mining activities have resulted in the loss of forest cover in the mining area, as well as its peripheral zone, which was under the dense cover of tropical dry deciduous forest before mining operation. The study revealed that the different age series mine overburden spoils in chronosequence showed gradual improvement in different soil features over time, which indicates the pace and progress of reclamation. Considering the different soil parameters of NF as unit, proportionate level of these parameters for different mine overburden sites were calculated. Further attempt was made to calculate the time period required for reclamation of $\mathrm{OB}_{0}$ to reach the nearby NF soil condition. Accordingly, a positive correlation was observed $(\mathrm{r}=0.996 ; p<0.001)$ between the mean soil feature value and age of mine overburden, which explained $99.69 \%$ of the variation in age, due to the change in mean soil features (Figure 2). Taking the value of the forest soil data (i.e. 1) as ' $X$ ', the equation was used to calculate the age of NF soil, i.e. 27.97 years.

\section{Conclusion}

Soil quality is intimately related to physico-chemical properties,

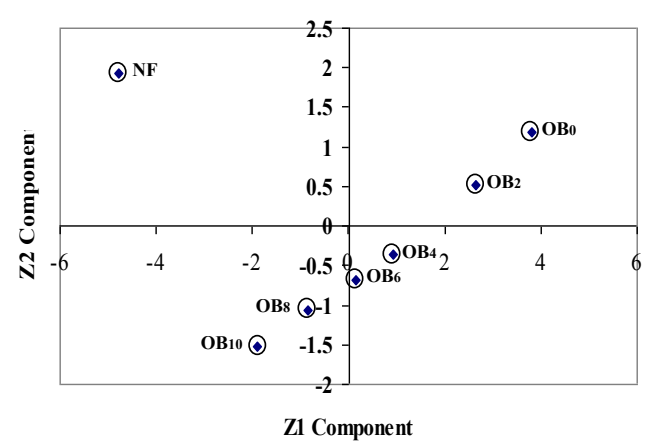

Figure 1: Segregation/discrimination analysis of different mine overburden spoil in chronosequence $\left(\mathrm{OB}_{0} \rightarrow \mathrm{OB}_{10}\right)$ and the native forest soil (NF).

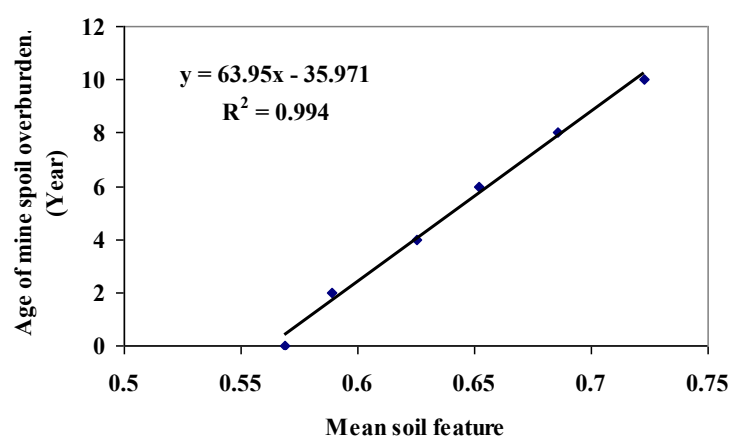

Figure 2: Relationship between mean soil features with age of the mine spoil overburdens.

and their evaluation will facilitate to characterize soil fertility and productivity. Soil physico-chemical indices appeared to be more informative, and could therefore be used to guide the selection of appropriate additional reclamation strategies. Soil physico-chemical characterization between different mine overburden spoils in chronosequence reflected changes in soil textural and structural attributes, organic carbon, total nitrogen and extractable phosphorus, which is due to the gradual establishment of vegetation in due course of time. Significant correlation between clay fraction and organic carbon indicated their potential utility, as rapid assessment tools for mine spoil reclamation. Besides, soil textural distribution is a major factor influencing water holding capacity, bulk density and soil moisture availability. Gradual increment in soil $\mathrm{pH}$, from acid mine spoils to neutral range in chronosequence, also revealed the sign of restoration. Increases in the organic carbon, nitrogen and phosphorous content in chronosequence mine overburden spoil during the $10 \mathrm{yr}$ period, clearly demonstrated their $\mathrm{C}$ sink potential. The lower level of organic carbon in mine overburden spoils, as compared to native forest soil, might be due to the disruption of ecosystem functioning, depletion of soil organic pool, and also due to the loss of litter layer during mining, which is an integral storage and exchange site for nutrients. The study suggested that the fresh mine spoil to attain the soil features of native forest soil through the process of reclamation shall take $\sim 28$ years, provided the spoil habitat is not subjected to any other interferences like erosion, vegetational degradation, etc.

\section{Acknowledgements}

We are indebted to many who helped with field, laboratory and statistical analysis during the course of the study. In particular, we would like to thank Department of Science and Technology (DST), Govt. of India for providing financial assistance and support (Grant registration No.: SERC/LS-0623/2010), under Science and Engineering Research Board (SERB).

\section{References}

1. Younos TM, Shanholtz VO (1980) Soil texture and hydraulic properties of postmining soil as related to the pre-mining soil horizons. In: Proc-1980 symposium on surface mining hydrology, sedimentology, and reclamation, University of Kentucky Lexington, KY, USA.

2. Pederson TA, Rogowski AS, Pennock R (1980) Physical characteristics of some minesoils. Soil Sci Soc Am J 44: 321-328.

3. Silburn DM, Crow FR (1984) Soil properties of surface mined land. Trans ASAE 27: 827-832.

4. Toy TJ, Shay D (1987) Comparison of some soil properties on natural and reclaimed hill slopes. Soil Sci 143: 264-277.

5. Botkin DB, Estes JE, Caswell MF, Orio AA (1989) Changing the global environment. Perspectives on human involvement. Academic Press Inc London, UK. 
Citation: Jitesh Kumar M, Amiya Kumar P (2013) Physico-Chemical Characterization and Mine Soil Genesis in Age Series Coal Mine Overburden Spoil in Chronosequence in a Dry Tropical Environment. J Phylogen Evolution Biol 1: 101. doi:10.4172/2329-9002.1000101

6. Johnson CD, Skousen J (1995) Minesoil properties of 15 abandoned mine land sites in West Virginia. J Environ Qual 24: 635-643.

7. Jha AK, Singh JS (1991) Spoil characteristics and vegetation development of an age series of mine spoils in a dry tropical environment. Vegetatio 97: 63-76.

8. Mummey D, Stahl PD, Buyer J (2002) Microbial markers as an indicator of ecosystem recovery following mine reclamation. Appl Soil Ecol 21: 251-259.

9. Soulliere EJ, Toy TJ (1986) Rilling of hillslopes reclaimed before 1977 surface mining law, Dave Johnston mine, Wyoming. Earth Surf Process Landforms 11 293-305.

10. Keefer RF, Sajwan KS (1993) Trace elements in coal and coal combustion residues (Advances in Trace Substances Research). CRC Press, USA.

11. Ciolkosz EJ, Cronce RC, Cunningham RL, Petersen GW (1985) Characteristics, genesis and classification of Pennsylvania minesoils. Soil Sci 139: 232-238.

12. Roberts JA, Daniels WL, Bell JC, Burger JA (1988) Early stages of mine soil genesis as affected by top soiling and organic amendments. Soil Sci Soc Am J 52: $730-738$

13. Hearing KC, Daniels WL, Roberts JA (1993) Changes in mine soil properties resulting from overburden weathering. J Environ Qual 22: 194-200.

14. Bell TJ, Ungar IA (1981) Factors affecting the establishment of natura vegetation on a coal strip mine spoil bank in southeastern Ohio. Am Midl Nat 105: 19-31.

15. McSweeney K, Jansen IJ (1984) Soil structure and associated rooting behavior in minesoils. Soil Sci Soc Am J 48: 607-612.

16. Schafer WM (1984) Mine-soil restoration and maturity: a guide for managing mine-soil development. Proc Symp Surface Coal Mining and Recla Grea Plains 172-185.

17. Nath A (2004) Ecosystem approach for rehabilitation of coal mine areas. Proceedings of the National Seminar on Environmental Engineering with special emphasis on Mining Environment, NSEEME-2004, India.

18. Juwarkar AA, Jambulkar HP, Singh SK (2004) Appropriate strategies for reclamation and revegetation of coal mine spoil dumps. Proceedings of the National Seminar on Environmental Engineering with special emphasis on Mining Environment, NSEEME-2004, India.

19. Wali MK (1979) Ecology and coal resource development. Volume 2, Pergamon press, New York, USA

20. Visser S, Zak J, Parkinson D (1979) Effects of surface mining on soil microbial communities and processes. In: Ecology and coal resource development, Wal MK (Eds.), Volume 2, Pregamon press, New York, USA.

21. Visser S, Griffiths CL, Parkinson D (1983) Effects of surface mining on the microbiology of a prairie site in Alberta, Canada. Can J Soil Sci 63: 177-189.

22. Anderson JM, Ingram JSI (1993) Tropical soil biology and fertility: a Handbook of methods. ( $2^{\text {nd }}$ Edn), C.A.B. International, UK

23. Mishra R (1968) Ecology workbook. Oxford \& IBH Publishing Company, New Delhi, India.

24. Jackson ML (1964) Soil chemical analysis. Prentice-Hall, New Delhi, India.

25. Page AL (1983) Methods of soil analysis, Part- 2. chemical and microbiologica properties. Volume 2, Amer Society of Agronomy, Madison, USA.

26. Banerjee SK, Das PK, Mishra TK (2000) Microbial and nutritional characteristics of coal mine overburden spoils in relation to vegetation development. J Indian Soc Soil Sci 48: 63-68.

27. Dutta RK, Agarwal M (2002) Effect of tree plantations on the soil characteristics and microbial activity of coal mine spoil land. Trop Ecol 43: 315-324.

28. Narain P, Singh R, Singh K (1990) Influence of forest covers on physicochemical and site characteristics in Doon valley. The Indian Forester 116: 900 916.

29. Parr JF, Papendick RI (1997) Soil quality: relationship and strategies for sustainable dryland farming systems. Annal of Arid Zones 36: 181-191.

30. Khoshoo TN (1987) Perspectives in environmental management: Addresses delivered at the 73rd session of the Indian Science Congress. Oxford and IBH Publishing Company, New Delhi, India.

31. Vimmerstedt JP, House MC, Larson MM, Kasile JD, Bishop BL (1989) Nitrogen and carbon accretion on Ohio coal minesoils: influence of soil-forming factors. Landsc Urban Plan 17: 99-111.

32. Van Veen JA, Ladd JN, Amato K (1985) Turnover of carbon and nitrogen through the microbial biomass in a sandy loam and a clay soil incubated with $\left[{ }^{14} \mathrm{C}(\mathrm{U})\right]$ glucose and $\left[{ }^{15} \mathrm{~N}\right]\left(\mathrm{NH}_{4}\right)_{2} \mathrm{So}_{4}$ under different moisture regimes. Soil Biol Biochem 17: 747-756.

33. Gregorich EG, Voroney RP, Kachanoski RG (1991) Turnover of carbon through the microbial biomass in soils with different texture. Soil Biol Biochem 23: 799805

34. Varela C, Vazquez C, Gonzalez-Sangregio MV, Leiros MC, Gil-Sotres F (1993) Chemical and physical properties of opencast lignite minesoils. Soil Sci 156 193-204.

35. Roberts RD, Marrs RH, Skeffington RA, Bradshaw AD (1981) Ecosystem development on naturally colonized china clay wastes: I. vegetation changes and overall accumulation of organic matter and nutrients. J Ecol 69: 153-161.

36. Marrs RH, Roberts RD, Skeffington RA, Bradshaw AD (1981) Ecosystem development on naturally colonized china clay wastes: II. Nutrient compartmentation. J Ecol 69: 163-169.

37. Marshman NA, Marshall KC (1981) Bacterial growth on proteins in the presence of clay minerals. Soil Biol Biochem 13: 127-134.

38. Dixon JB (1989) Minerals in soil environments. ( $2^{\text {nd }}$ Edn), Soil Science Society of America, USA

39. Van Veen JA, Kuikman PJ (1990) Soil structural aspects of decomposition of organic matter by micro-organisms. Biogeochemistry 11: 213-233.

40. Gupta VVSR, Germida JJ (1988) Distribution of microbial biomass and its activity in different soil aggregate size classes as affected by cultivation. Soil Biol Biochem 20: 777-786.

41. Prinsley RT, Swift MJ (1987) Amelioration of soil by trees: a review of current concepts and practices. Commonwealth Science Council, London, UK.

42. Garcia C, Hernandez T, Barahona A, Costa F (1996) Organic matter characteristics and nutrient content in eroded soils. Environ Manage 20: 133 141.

43. Foissner W (1992) Comparative studies on the soil life in ecofarmed and conventionally farmed fields and grasslands of Austria. Agril Ecosyst Environ 40: $207-218$

44. Brady NC (1990) The nature and properties of soils. (10 ${ }^{\text {th }}$ Edn), Macmillan, New York, USA.

45. Ohta S, Effendi S (1992) Ultisol of "lowland Dipterocarp forest" in eas Kalimantan, Indonesia. Soil Sci Plant Nutr 38: 197-206.

46. Bauer A, Black AL (1994) Quantification of the effect of soil organic matter content on soil productivity. Soil Sci Soc Am J 58: 185-193.

47. Sahani U, Behera N (2001) Impact of deforestation on soil physicochemical characteristics, microbial biomass and microbial activity of tropical soil. Land Degradation and Development 12: 93-105

48. Bird PR, Lynch JJ, Obst JM (1984) Effect of shelter on plant and animal production. Pros Aust Sos Anim Prod 15: 270-273.

49. Cremer KW (1990) Trees for rural Australia. Inkata press, Australia

50. Russell WB, La Roi GH (1986) Natural vegetation and ecology of abandoned coal-mined land, Rocky Mountain Foothills, Alberta, Canada. Can J Bot 64 1286-1298.

51. Srivastava SC (1999) Effect of coal mining on microbial biomass and nutrient availability in dry tropical forest of Vindhyan hill region. J Trop Forestry 15 $15-23$

52. Suzuki I, Lee D, Mackay B, Harahuc L, Oh JK (1999) Effect of various ions, $\mathrm{ph}$, and osmotic pressure on oxidation of elemental sulfur by Thiobacillus thiooxidans. Appl Environ Microbiol 65: 5163-5168.

53. Young A (1989) Agroforestry for soil conservation. ICRAF, CAB International, UK

54. Sahani U, Behera N (1998) Impact of deforestation on physico-chemical properties of tropical soil. Indian J Env and Ecoplan 1: 33-38.

55. Srivastava SC, Jha AK, Singh JS (1989) Changes with time in soil biomass 
Citation: Jitesh Kumar M, Amiya Kumar P (2013) Physico-Chemical Characterization and Mine Soil Genesis in Age Series Coal Mine Overburden Spoil in Chronosequence in a Dry Tropical Environment. J Phylogen Evolution Biol 1: 101. doi:10.4172/2329-9002.1000101

$\mathrm{C}, \mathrm{N}$ and $\mathrm{P}$ of mine spoils in a dry tropical environment. Can J Soil Sci 69 : 849-855.

56. Garcia C, Hernández T (1997) Biological and biochemical indicators in derelict soils subject to erosion. Soil Biol Biochem 29: 171-177.

57. Barnhisel RI (2000) Reclamation of drastically disturbed lands. American Society of Agronomy, Madison, WI, USA.

58. Jencks EM, Tryon EH, Contri M (1982) Accumulation of nitrogen in minesoils seeded to black locust. Soil Sci Soc Am J 46: 1290-1293.
59. Dancer WS, Handley JF, Bradshaw AD (1977) Nitrogen accumulation in kaolin mining wastes in cornwall. Plant Soil 48: 303-314.

60. Rimmer DL (1982) Soil physical conditions on reclaimed colliery spoil heaps. J Soil Sci 33: 567-579.

61. Gordon JC, Wheeler CT (1983) Biological nitrogen fixation in forest ecosystem Foundations and Applications. Forestry, Springer Publishers,New York, USA

62. Ludwig JA, Reynolds JF (1988) Statistical ecology: A primer in method and computing. John Wiley and Sons, USA. 